\title{
EVALUATION OF TISSUE RESPONSE TO PERIODONTAL DRESSINGS: HISTOLOGICAL STUDY IN TOOTH SOCKETS OF RATS
}

\author{
Célia Tomiko Matida Hamata SAITO ${ }^{1}$, Pedro Felício Estrada BERNABÉ ${ }^{2}$, Tetuo OKAMOTO ${ }^{3}$, Sueli Satomi MURATA ${ }^{4}$, \\ Marcelo Matida HAMATA ${ }^{1}$, Maria Lúcia Marçal Mazza SUNDEFELD
}

1- DDS, MS, Postgraduate Student in Dentistry, Dental School of Araçatuba, State University of São Paulo, Araçatuba, SP, Brazil.
2- DDS, PhD, Department of Restorative Dentistry, Dental School of Araçatuba, State University of São Paulo, Araçatuba, SP, Brazil.
3- DDS, PhD, Department of Surgery and Integrated Clinic, Dental School of Araçatuba, State University of São Paulo, Araçatuba, SP, Brazil.
4- DDS, PhD, Postgraduate Student in Dentistry, Dental School of Araçatuba, State University of São Paulo, Araçatuba, SP, Brazil.
5- DDS, PhD Department of Pediatric and Social Dentistry, Dental School of Araçatuba, State University of São Paulo, Araçatuba, SP, Brazil.

Corresponding address: Célia T. M. H. Saito - Rua José Bonifácio Street, 1193 - 16015-050 - Araçatuba - SP - Brazil - Phone: 55183636 2822 - Fax: +551836363332 - e-mail: celiatomiko@foa.unesp.br

Received: October 27, 2007 - Modification: November 07, 2007 - Accepted: March 7, 2008

\begin{abstract}
$A$

lthough the use of periodontal dressings is currently limited, there are some indications for their use. Selection of any material that will have direct contact with live tissues, such as periodontal dressings, should be careful in order to allow surgical wound healing. The aim of this study was to evaluate the intensity of inflammatory response and bone formation in tooth sockets of rats after implantation of three periodontal dressings. After removal of the right maxillary incisors of 84 male rats, each tooth socket received implantation of a polyethylene tube, 63 of which were filled with non-eugenol periodontal dressing and the remaining 21 tubes remained empty (control group). Histological evaluation assessed the intensity of inflammatory response and presence and location of bone tissue formation at postoperative periods of 7, 14 and 28 days. Statistical analysis was performed by the Kruskal-Wallis test at $5 \%$ significance level. Regarding the inflammatory infiltrate, at 28 days, there was statistically significant difference between one of periodontal dressings and control group ( $<<0.05$ ). Analysis of postoperative periods, showed that the control group presented statistically significant reduction in the inflammatory infiltrate comparing the 14- and 28-day periods $(\mathrm{p}<0.05)$. Regarding bone tissue formation, there was difference in control group between the 7 - and 28 -day periods $(\mathrm{p}<0.05)$. Within the experimental conditions, it may be concluded that no differences were found in the inflammatory response among the groups at 7 and 14 days and that Voco pac ${ }^{\mathrm{TM}}$ dressing induced a more intensive inflammatory reaction at 28 days.
\end{abstract}

Keywords: Dental materials. Periodontal dressings. Biocompatible materials.

\section{INTRODUCTION}

Periodontal dressings were first introduced in 1923 when Ward ${ }^{22}$ advocated the use of a paste derived from eugenolate to protect the wound areas. Since then, periodontal dressings have been studied ${ }^{1,7,15,16,17,19}$.

Currently, the indication of periodontal dressings has been limited. However, in apically repositioned flap surgeries $^{2}$, the use of dressings is justified to help preventing coronal flap displacement. In free gingival grafts, despite the presence of sutures, an additional support with periodontal dressing provides benefits ${ }^{12}$. In non-surgical procedures, use of dressings may be valuable in patients with aggressive periodontitis ${ }^{18}$.

In summary, despite the large advances in contemporary surgical techniques, there are several clinical situations in which indication of periodontal dressing is advantageous ${ }^{4,12,13}$. Selection of any material that will have direct contact with live tissues, such as periodontal dressings, should be careful in order to allow surgical wound repair.

This study evaluated histologically and semiquantitatively the intensity of inflammatory response and bone formation after implantation of polyethylene tubes containing periodontal dressings in tooth sockets of rats.

\section{MATERIALAND METHODS}

The research protocol was approved by the São Paulo 
Sate University Dental School of Araçatuba Animal Research Care Committee, according to protocol \#26/04.

The study sample was composed of 84 male rats (Rattus norvegicus albinus, Wistar), weighing nearly $250 \mathrm{~g}$, which were fed solid pelleted food (Guabi Nutrilabor, Mogiana Alimentos SA, Campinas, SP, Brazil) and water ad libitum.

For implantation in the subcutaneous tissue, the materials were packed in 84 polyethylene tubes (Embramed Ind. Com. Ltda., São Paulo, Brazil) with 1.0-mm internal diameter, 1.67-mm external diameter and 3.0-mm length. Each tube had one end sealed with an 1.0-mm-thick layer of guttapercha (Tanari, Tanariman Industrial Ltda. Manacapuru, Brazil) and the remaining $2.0 \mathrm{~mm}$ were filled with the periodontal dressings: Coe-pak ${ }^{\mathrm{TM}}$ (GC America Inc., Alsip, IL, USA), Perio Bond ${ }^{\mathrm{TM}}$ (Dentsply Ind. e Com. Ltda, Petrópolis, RJ, Brazil) and Voco pac ${ }^{\mathrm{TM}}$ (Voco $\mathrm{GmbH}$, Cuxhaven, Germany). The tubes were filled with the aid of a syringe (Seringa Mark IIIp/ tubo AccuDose High Viscosity, Centrix Incorporated, Shelton, CT, USA) immediately after preparation of the dressings according to the manufacturers' instructions at a controlled room temperature of $25^{\circ} \mathrm{C}$. In the control group, the space corresponding to the dressing was

\section{left empty.}

The 84 rats were assigned to 4 groups of 21 animals each, as follows: Group I (control), the polyethylene tubes did not contain any periodontal dressing; in Groups II, III and IV, the tubes contained Coe-pak ${ }^{\mathrm{TM}}$. Perio Bond ${ }^{\mathrm{TM}}$ and Voco pac ${ }^{\mathrm{TM}}$, respectively.

For the surgical procedures, the animals were sedated with an intramuscular injection of $2 \%$ xylazine (Coopazine, Coopers, São Paulo, SP, Brazil; $10 \mathrm{mg} / \mathrm{kg}$ body weight and then anesthetized with 5\% ketamine hydrochloride (Vetanarcol, König do Brasil, São Paulo, SP, Brazil; $25 \mathrm{mg} / \mathrm{kg}$ body weight). After anesthetics and antisepsis with 10\% PVP-I (Asteriodine, Áster Produtos Médicos Ltda., Sorocaba, SP, Brazil) of the anterior maxillary region, both externally and internally at the region of maxillary incisors, the animals had the maxillary right incisor extracted. After socket bleeding control with gauze, the polyethylene tubes were implanted, in such a way that the end containing the periodontal dressing was turned towards the bottom of the socket. A\#2 Peter Thomas instrument with an adaptation in the curvature and an endodontic stop (Maillefer, Dentsply, Ballaigues, Switzerland) was used to help in implantation

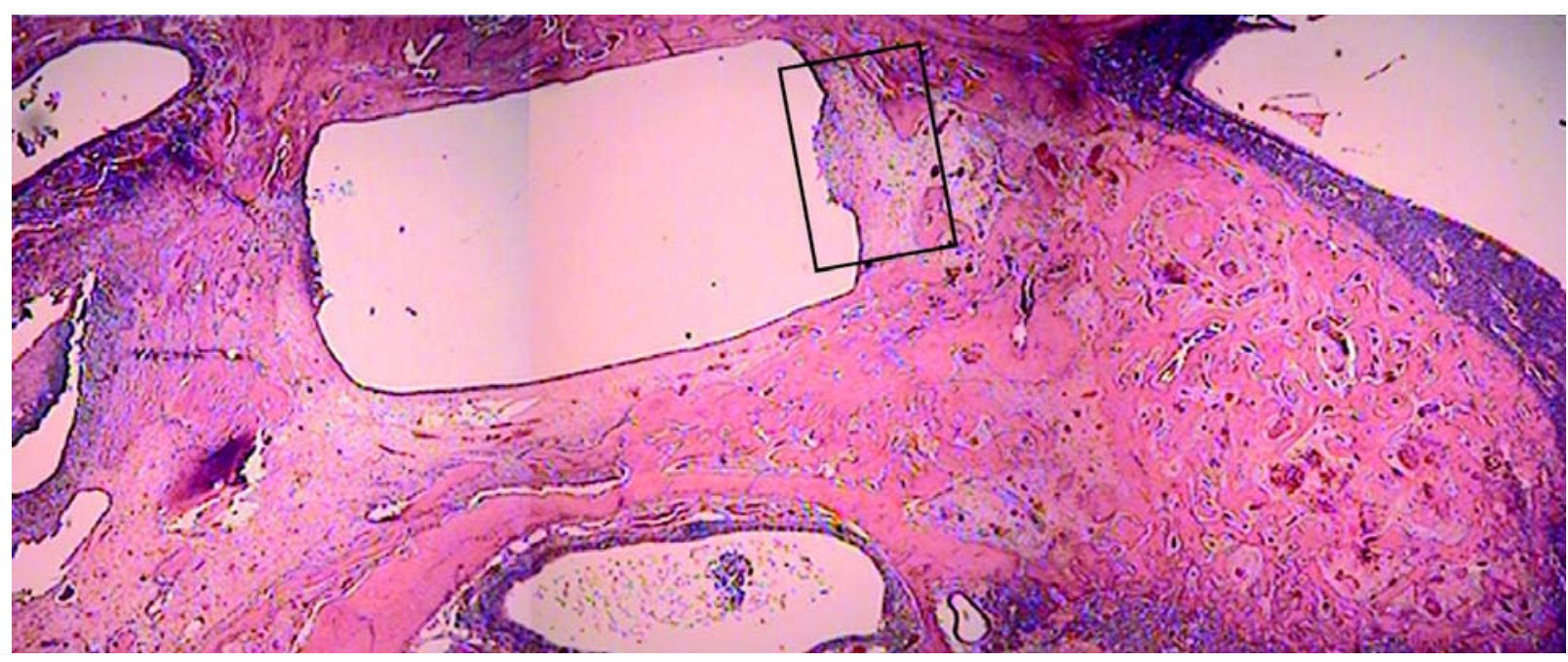

FIGURE 1- Histological section showing the tooth socket containing a polyethylene tube at the middle third. Note the area examined histologically (rectangle)

TABLE 1- Results of variables inflammatory infiltrate and presence and location of bone tissue formation

\begin{tabular}{lllllll}
\hline Variable & $\begin{array}{l}\text { Group I } \\
\text { Mean (SD) }\end{array}$ & $\begin{array}{l}\text { Group II } \\
\text { Mean (SD) }\end{array}$ & $\begin{array}{l}\text { Group III } \\
\text { Mean (SD) }\end{array}$ & $\begin{array}{l}\text { Group IV } \\
\text { Mean (SD) }\end{array}$ & KW & p \\
\hline Inflammatory infiltrate $-7 d$ & $3.43(0.98)$ & $3.57(0.79)$ & $3,57(0.53)$ & $3.43(0.79)$ & 0.2162 & 0.9749 \\
Inflammatory infiltrate - 14d & $3.57(0.79)$ & $3.71(0.49)$ & $3.57(0.79)$ & $3.14(0.90)$ & 2.110 & 0.5499 \\
Inflammatory infiltrate - 28d & $2.10(0.38)$ & $3.00(0.82)$ & $3.20(0.75)$ & $3.50(0.55)$ & 10.77 & $0.0131^{*}$ \\
Bone tissue formation - 7d & $3.14(0.38)$ & $2.86(0.38)$ & $3.14(0.38)$ & $3.00(0.58)$ & 2.115 & 0.5489 \\
Bone tissue formation - 14d & $2.57(0.53)$ & $2.57(0.53)$ & $3.00(0.63)$ & $2.86(0.38)$ & 3.041 & 0.3853 \\
Bone tissue formation - 28d & $2.00(0.0)$ & $2.71(0.49)$ & $2.67(0.52)$ & $2.33(0.52)$ & 8.867 & $0.0311^{*}$ \\
\hline
\end{tabular}

$\mathrm{SD}=$ standard deviations; $\mathrm{KW}=$ Kruskal-Wallis; * Significant difference at $\mathrm{p}<0.05$. 

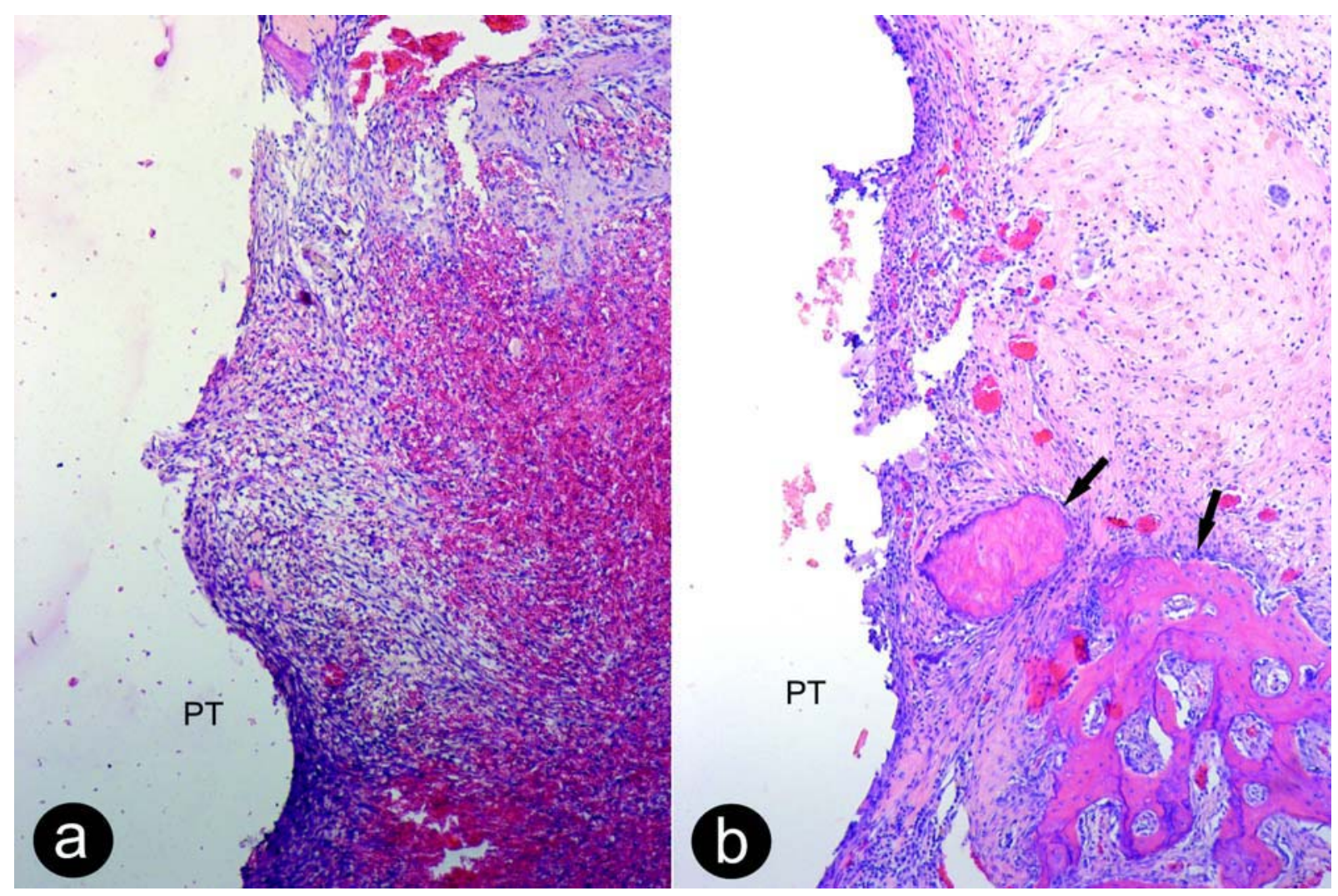

FIGURE 2- This image shows the behavior of Group I at 7 days (a) and 28 days (b) close to the polyethylene tubes (PT). The arrows indicate bone tissue formation. HE, original magnification $100 \mathrm{X}$

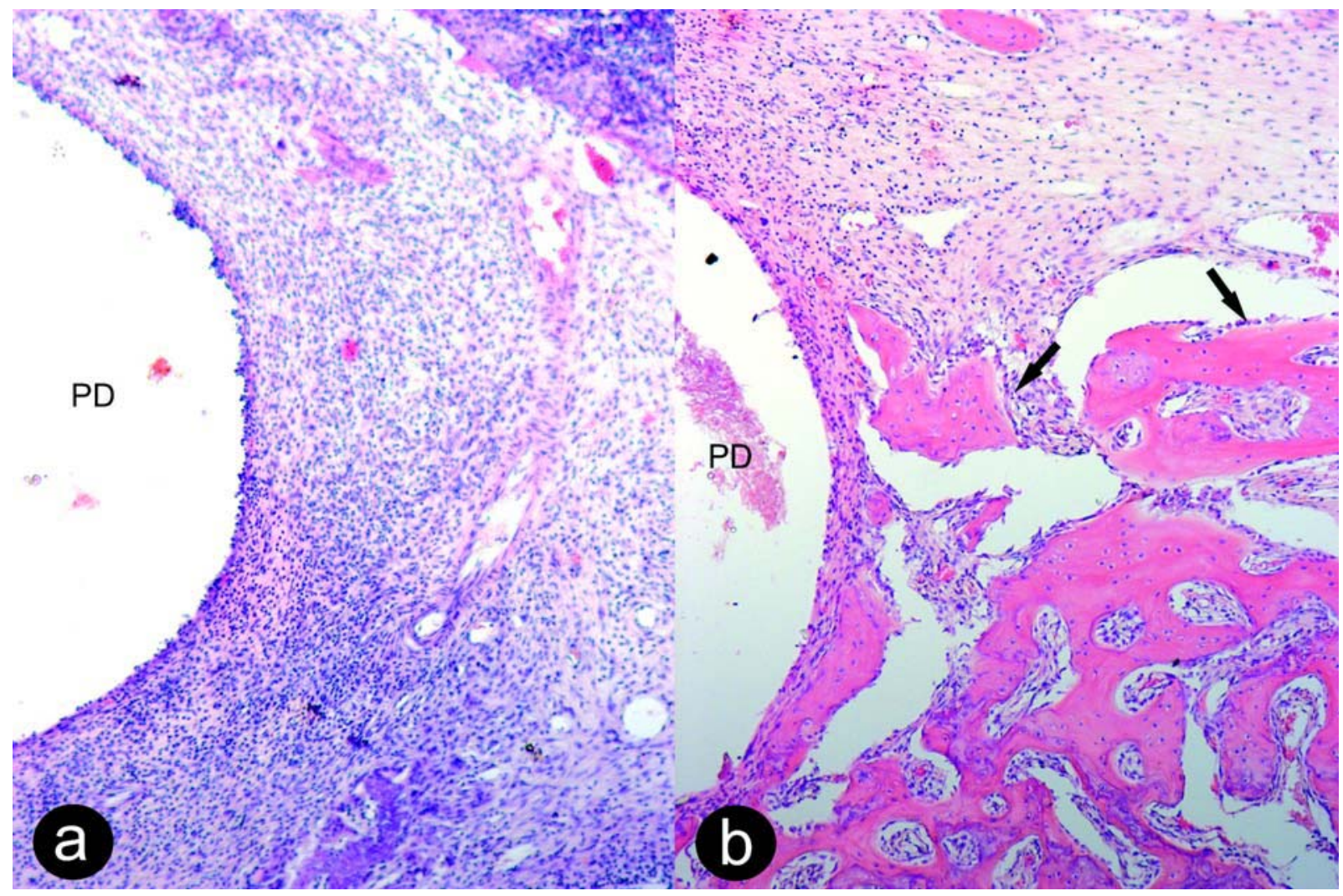

FIGURE 3- This image shows the behavior of Group II at 7 days (a) and 28 days (b) close to the periodontal dressing (PD). The arrows indicate bone tissue formation. HE, original magnification 100X 


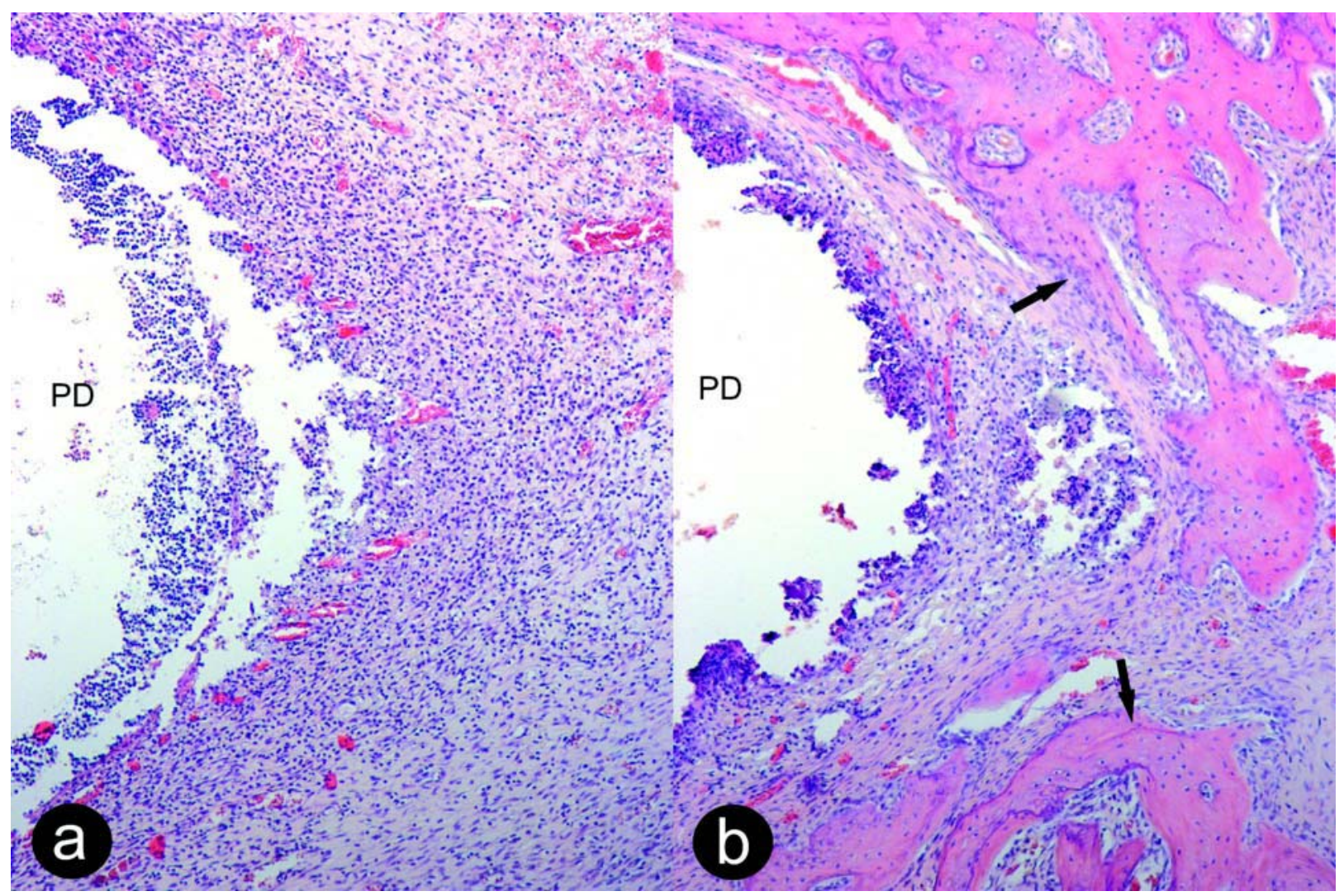

FIGURE 4- This image shows the behavior of Group III at 7 days (a) and 28 days (b) close to the periodontal dressing (PD). The arrows indicate bone tissue formation. HE, original magnification $100 \mathrm{X}$

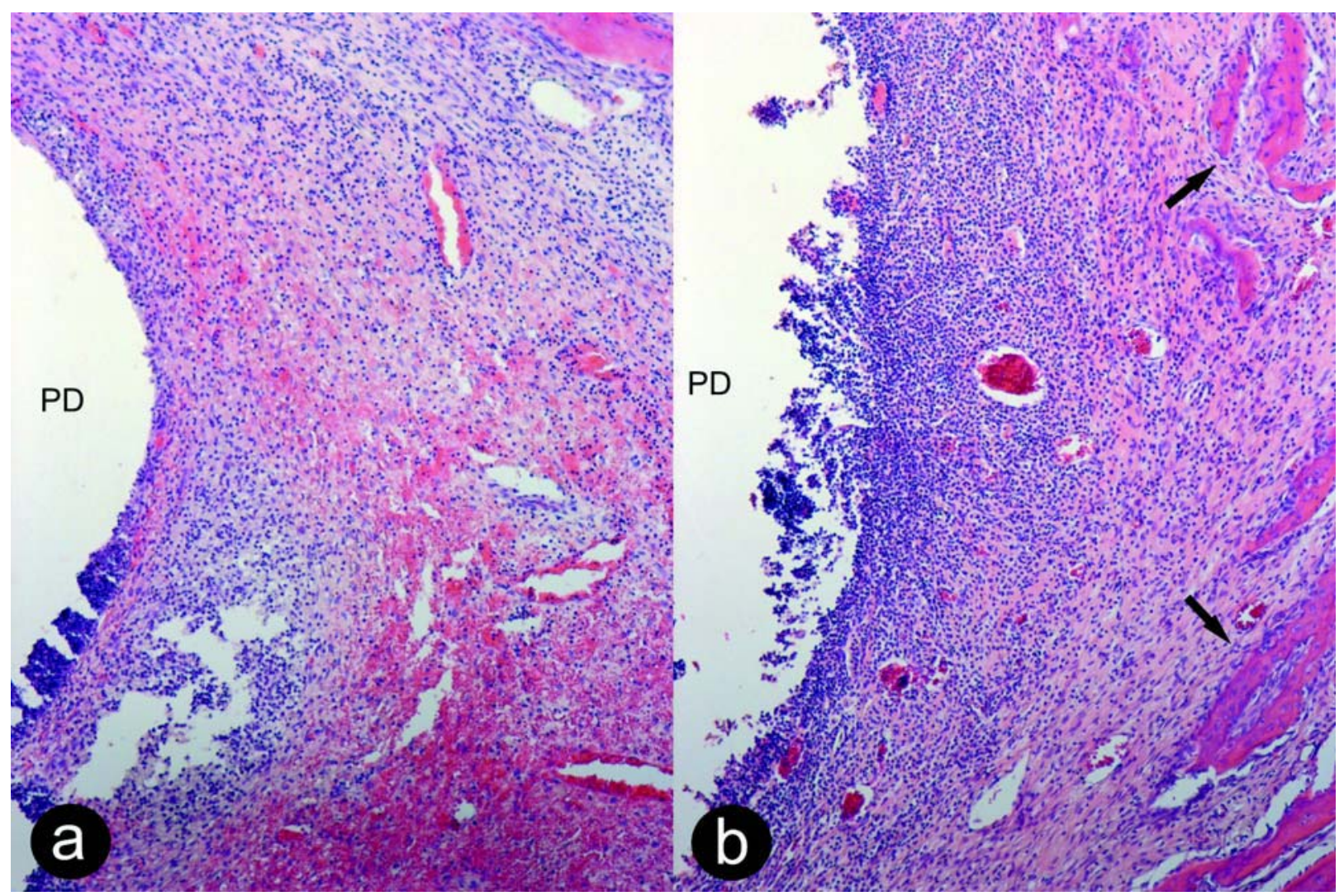

FIGURE 5- This image shows the behavior of Group IV at 7 days (a) and 28 days (b) close to the periodontal dressing (PD). The arrows indicate bone tissue formation. HE, original magnification $100 \mathrm{X}$ 
and to standardize the depth of implantation at $6 \mathrm{~mm}$. After implantation, approximation of the gingival margins and suture were performed with simple sutures using silk suture 4.0 (Ethicon, Johnson \& Johnson Ind. Comércio Ltda., São José dos Campos, SP, Brasil) with an atraumatic needle.

The animals were killed after 7,14 and 28 days for histological evaluation. The right hemimaxilla containing the tooth socket with the implanted tube were fixed in $10 \%$ formalin solution for $48 \mathrm{~h}$ and then washed in running tap water for $24 \mathrm{~h}$ for removal of the fixative. The specimens were decalcified in $17 \%$ EDTA solution, dehydrated, clarified and embedded in paraffin, allowing histological sections of the socket in longitudinal direction. Serial 6- $\mu \mathrm{m}$-thick sections were obtained and stained with hematoxylin and eosin (HE) for histological analysis. The area adjacent to the periodontal dressing was examined (Figure 1), assessing the occurrence of inflammatory cell infiltrate and presence and location of bone tissue formation. The inflammatory infiltrate was evaluated according to the modified Wolfson and Seltzer ${ }^{23}$ criteria. Scores 1, 2, 3 and 4 were attributed depending on the number of inflammatory cells (Table 1), corresponding to absent inflammatory cells, few inflammatory cells, moderate density of inflammatory cells, and great density of inflammatory cells, respectively, at 400X magnification.

The presence and location of bone tissue formation was classified as score 1, when in contact with the material; score 2 , when there was bone tissue formation close to the material, at the middle and apical thirds of the socket; score 3, when this formation was distant from the material, only at the apical third; and score 4, when bone tissue formation was absent (Table 1).

Data were analyzed statistically by non-parametric Kruskal-Wallis (KW) test and Dunn's post test, using GraphPad Prism ${ }^{\mathrm{TM}} 3.0$ software (GraphPad Software Inc., San Diego, California, USA). Intragroup and intergroup comparisons were performed at the three study periods, for each analyzed variable.

\section{RESULTS}

\section{Histologic Analysis}

Group I (Control): At 7 days postoperatively, most specimens presented connective tissue with moderate amount of macrophages and lymphocytes (Figure 2A) with small newly formed bone trabeculae at most distant areas. At 14 days, the characteristics were similar to those of the previous period, with small isolated bone trabeculae. At 28 days, some specimens presented thin bone trabeculae close to the tube opening (Figure 2B).

Group II: At 7 days postoperatively, there was poorly organized connective tissue with great amount of macrophages and lymphocytes (Figure 3A). At 14 days, the characteristics were similar to the previous period with thin newly formed bone trabeculae. At 28 days, most specimens exhibited connective tissue with some macrophages and lymphocytes. There were bone trabeculae partially filling the area close to the periodontal dressing (Figure 3B).
Group III: At 7 days postoperatively, most specimens presented several polymorphonuclear neutrophils close to the periodontal dressing, some of which were degenerating (Figure 4A). At 14 days, the characteristics were similar to the previous period, with thin newly formed bone trabeculae. At 28 days, most cases presented inflammatory cells close to the periodontal dressing, and connective tissue with welldeveloped bone trabeculae (Figure 4B).

Group IV: At 7 days and 14 days postoperatively, most specimens presented degenerating cells, several macrophages and lymphocytes contacting the periodontal dressing, (Figure 5A). At 28 days, there was a small number of degenerating cells contacting the periodontal dressing; extensive areas filled by poorly organized connective tissue with moderate density of macrophages, lymphocytes and thin bone trabeculae (Figure 5B).

\section{Inflammatory Response and New Bone Formation}

With regard to the inflammatory infiltrate (Table 1), there was no statistically significant difference among groups at the 7- and 14-day periods. At 28 days (Figure 4), there was statistically significant difference with a larger number of inflammatory cells in group IV compared to group I (Figure 3 ). Analysis of the inflammatory infiltrate for the postoperative periods revealed that group I presented a statistically significant reduction in the inflammatory infiltrate compared to the 14- and 28-day periods.

Considering the presence and location of bone tissue formation, there was no statistically significant difference among the periodontal dressings at the 28-day period; however, the three materials showed different behavior when compared to the control group. Analysis of the postoperative periods revealed that group I presented a significant greater bone tissue formation closer to the tube at 28 days compared to the 7-day period.

\section{DISCUSSION}

Experimental studies in animals have been used to evaluate the biocompatibility of periodontal dressings. This method has been conducted by implant placement in the subcutaneous connective tissue of rats, ${ }^{15,16}$ analysis of periodontal tissues after simulation of periodontal surgical procedure in rats $^{8}$ and cranial implants juxtaposed to periosteum and bone tissue in rats ${ }^{11}$. Subcutaneous implantation in rats is very useful and applicable due to the ease of accomplishment. However, it is limited to the analysis of the reaction of histopathological events in the soft tissues. Moreover, Marion, et al. ${ }^{14}$ have stated that the degree of tissue response depends on the technique and animal model. The main problems observed after implantation in rat subcutaneous connective tissue are the effect of acute operative trauma, loss of material/tissue interface, tissue displacement or tearing when the material is removed, folds or distortions in the tissue and difficulties in specimen arrangement during microtomy. These difficulties were not 
observed in the present study, since rat socket anatomy favored the aforementioned procedures.

Implantation in rat tooth sockets is a widely used method for evaluation of biocompatibility of endodontic ${ }^{6}$ and paraendodontic sealers ${ }^{5,6}$. In the present study, evaluation of biocompatibility of periodontal dressings in tooth extraction wounds was performed by implantation of polyethylene tubes into the sockets of rats immediately after extraction, filled with the materials under investigation. The polyethylene tubes employed for that purpose should be biocompatible. Torneck ${ }^{21}$ observed a mild inflammatory reaction induced by polyethylene tubes when implanted in the subcutaneous connective tissue of rats. The tubes were circumscribed by a non-infiltrative connective capsule with collagen fibers and cells arranged parallel to the surface, with small thickness, characterizing excellent material. Also, there was connective tissue formation inside the tubes, which encouraged their use in several studies on dental materials.

In the present study, alveolar bone response to implantation of empty polyethylene tubes at the 7- and 14day periods revealed two different patterns of reaction as to the inflammatory process. Some specimens exhibited a small number of inflammatory cells, indicating good biological compatibility of the implanted material, corroborating the findings of Torneck ${ }^{21}$. However, in most cases, histological analysis revealed the presence of a large number of inflammatory cells, indicating acute inflammatory reaction. Comparison to the data described by Torneck ${ }^{21}$ revealed agreement only as to the biocompatibility of tubes implanted in subcutaneous tissue at the 28th postoperative day. This diverging result may have occurred due to the differences existing in the comparison of subcutaneous and intrasocket environments. Further studies should be conducted to investigate such disagreement.

Care should be taken in the interpretation of results of studies on materials with potential to induce severe inflammatory reaction, such as periodontal dressings, especially when associated with polyethylene tubes, because there are some peculiarities inherent to tooth socket, as previously mentioned. Blood supply is abundant in the socket, as well as in other oral structures. This provide a better local defense, which is necessary to combat infections yet may also lead to more severe reactions against the implantation of foreign materials, such as polyethylene tubes.

At the 28-day period, Voco pac ${ }^{\mathrm{TM}}$ dressing presented a severe inflammatory reaction, in agreement with the findings of Alpar, et $\mathrm{al}^{1}$. These authors evaluated the cytocompatibility of periodontal dressings Coe-pak ${ }^{\mathrm{TM}}$ and Voco pac ${ }^{\mathrm{TM}}$ in cultures of primary gingival fibroblasts and human osteoblast-like cells and mice fibroblasts, and concluded that Coe-pak ${ }^{\mathrm{TM}}$ and Voco pac ${ }^{\mathrm{TM}}$ dressings exhibited moderate or severe cytotoxic effect. This indicates that the cytotoxic substances released by these materials may interfere with the repair process of periodontal tissues after application. Other studies conducted on the Coe-pak ${ }^{\mathrm{TM}}$ dressing report its cytotoxic effect ${ }^{7,10}$. The mechanism in charge of this effect is unknown, yet it is known that, after manipulation, the dressing may release a large amount of non-specific substances with cytotoxic effects ${ }^{10}$. Moreover, Haugen, et al. ${ }^{9}$ have reported that the composition of the periodontal dressing Coe-pak ${ }^{\mathrm{TM}}$ contains substances with antibacterial effect, whose release might trigger a severe inflammatory reaction. However, the results of the present study do not reflect the same results.

According to Sunzel ${ }^{20}$, the combination of colophony and zinc in the composition of periodontal dressings may present cytotoxic effects that should be further investigated. Among the periodontal dressings evaluated in the present study, only Voco pac ${ }^{\mathrm{TM}}$ mentions the presence of colophony in its composition. This fact may have influenced the results, especially at the 28-day postoperative period, in which the inflammatory response to this dressing was more severe.

Perio Bond ${ }^{\mathrm{TM}}$ presented moderate or severe density of inflammatory cells in all the postoperative times, reported elsewhere ${ }^{15}$. However, it was difficult to compare our results to those of other works because the literature is scarce in studies with this material.

Different phases of alveolar wound healing were observed by histological examination after dental extraction. At the end of the first week, newly formed trabecular bone was observed mainly on the internal surfaces of the alveolar socket as well as blood clot and granulation tissue remnants with moderate lymphocyte infiltration. At the second week on, there were progressive new bone formation and decrease in the inflammatory infiltrate and blood clot extension. At the end of the third week, a network of thicker bone trabeculae surrounding interconnecting spaces filled with medullar connective tissue were observed occupying the socket ${ }^{3}$. Regarding bone tissue formation, the difference observed between the 7- and 28-day periods demonstrated that there is new bone tissue formation, although slower than in the previously described alveolar wound healing ${ }^{3}$. This may have occurred due to the intensive osteoblastic activity despite the presence of a foreign body in the tooth sockets. The proximity of the new bone formation to periodontal dressings or empty polyethylene tubes was inversely proportional to the amount of inflammatory cells.

It should be considered that the reactions triggered by the tested periodontal dressings occurred at regions others than those at which they were applied. The dressings are placed on gingival tissue, either covered or not by epithelium, periosteum or bone tissue and, in any case, they get in contact with the surgical wound. For this reason, biocompatibility studies are necessary. All efforts should be made to search for a dressing that may benefit or cause minimal irritation during the postoperative course.

Further studies should be conducted with new materials for wound protection, since a material that meets all ideal characteristics has not been found so far, especially from a biological standpoint. Efforts should be directed to enhance the repair of the periodontal surgical wound and, consequently, reestablish function and esthetics. 


\section{CONCLUSIONS}

Within the experimental conditions, it may be concluded that no differences were found in the inflammatory response among the groups at 7 and 14 days and that Voco pac ${ }^{\mathrm{TM}}$ dressing induced a more intensive inflammatory reaction at 28 days. Although an attempt to design and develop a new model system to investigate inflammatory process has been made in this study, all periodontal dressings induced an intense inflammatory response and thus further research is needed to evaluate these materials.

\section{ACKNOWLEDGEMENTS}

The authors thank Voco GmbH (Cuxhaven, Germany) for supplying Voco pac ${ }^{\mathrm{TM}}$ dressing.

\section{REFERENCES}

1- Alpar B, Gunay H, Geurtsen W, Leyhausen G. Cytocompatibility of periodontal dressing materials in fibroblast and primary human osteoblast-like cultures. Clin Oral Investig. 1999;3(1):41-8.

2- Ariaudo AA, Tyrell HA. Repositioning and increasing the zone of attached gingival. J Periodontol. 1957;28(2):106-10.

3- Calixto RF, Teófilo JM, Brentegani LG, Lamano-Carvalho TL. Alveolar wound healing after implantation with a pool of commercially available bovine bone morphogenetic proteins (BMPs): a histometric study in rats. Braz Dent J. 2007;18(1):29-33.

4- Checchi L, Trombelli L. Postoperative pain and discomfort with and without periodontal dressing in conjunction with $0.2 \%$ chlorhexidine mouthwash after apically positioned flap procedure. J Periodontol. 1993;64(12):1238-42.

5- Cintra LT, de Moraes IG, Estrada BP, Gomes-Filho JE, Bramante $\mathrm{CM}$, Garcia RB, et al. Evaluation of the tissue response to MTA and MBPC: Microscopic analysis of implants in alveolar bone of rats. $\mathrm{J}$ Endod. 2006;32(6):556-9.

6- DeGrood ME, Oguntebi BR, Cunningham CJ, Pink R. A comparison of tissue reactions to Ketac-Fil and amalgam. J Endod. 1995;21(2):659 .

7- Eber RM, Shuler CF, Buchanan W, Beck FM, Horton JE. Effect of periodontal dressings on human gingiva fibroblasts in vitro. J Periodontol. 1989;60(8):429-34.

8- Haugen E. The effect of periodontal dressings on intact mucous membrane and on wound healing. A methodological study. Acta Odontol Scand. 1980;38(6):363-70.

9- Haugen E, Gjermo P, Orstavik D. Some antibacterial properties of periodontal dressings. J Clin Periodontol. 1977;4(1):62-8.

10- Haugen E, Hensten-Pettersen A. Evaluation of periodontal dressings by hemolysis and oral LD50 tests. J Dent Res. 1979;58(9):1912-3

11- Haugen E, Mjor IA. Bone tissue reactions to periodontal dressings. J Periodontal Res. 1979;14(1):76-85.

12- Kassab MM, Cohen RE. Treatment of gingival recession. J Am Dent Assoc. 2002;133(11):1499-506.
13- Lindhe J, Karring T, Lang NP. Clinical periodontology and implant dentistry . 4 th. Oxford: Blackwell Munksgaard, 2003.

14- Marion L, Haugen E, Mjor IA. Methodological assessments of subcutaneous implantation techniques. J Biomed Mater Res. $1980 ; 14(4): 343-57$.

15- Milanezi LA, Nagata MJH, Milanezi FM, Garcia VG. Biological reaction of subcutaneous connective tissue to periodontal dressings. Histological study in rats. Rev Cienc Odontol. 2001;4(4):35-42.

16- Nezwek RA, Caffesse RG, Bergenholtz A, Nasjleti CE. Connective tissue response to periodontal dressing. J Periodontol. 1980;51(9):521-

17- Petelin M, Pavlica Z, Batista U, Stiblar-Martincic D, Skaleric U. Effects of periodontal dressings on fibroblasts and gingival wound healing in dogs. Acta Vet Hung. 2004;52(1):33-46.

18- Sigusch BW, Pfitzner A, Nietzsch T, Glockmann E. Periodontal dressing (Voco pac ${ }^{\mathrm{TM}}$ ) influences outcomes in a two-step treatment procedure. J Clin Periodontol. 2005;32(4):401-5.

19- Smeekens JP, Maltha JC, Renggli HH. Histological evaluation of surgically treated oral tissues after application of a photocuring periodontal dressing material. An animal study. J Clin Periodontol. 1992;19(9 Pt 1):641-5.

20- Sunzel B, Soderberg TA, Johansson A, Hallmans G, Gref R. The protective effect of zinc on rosin and resin acid toxicity in human polymorphonuclear leukocytes and human gingival fibroblasts in vitro. J Biomed Mater Res. 1997;37(1):20-8.

21- Torneck CD. Reaction of rat connective tissue to polyethylene tube implants. II. Oral Surg Oral Med Oral Pathol. 1967;24(5):67483.

22- Ward AW. Inharmonious cusp relation as a factor in periodontoclasia. J Am Dent Assoc. 1923;10(6): 471-81.

23- Wolfson EM, Seltzer S. Reaction of rat connective tissue to some gutta-percha formulations. J Endod. 1975;1(12):395-402. 